\title{
The Sacred and the Secular: Practical Applications of Water Rituals in the Ifugao Agricultural System
}

\author{
Stephen Acabado and Marlon Martin
}

\begin{abstract}
Water symbolisms permeate Ifugao religion, rituals, and oral tradition. Water plays a part in death, rebirth, and cleansing in Ifugao cosmology. As such, Ifugaos consider water as sacred. However, water is also central in Ifugao economy and politics. As a culture that highly values intensive wet-rice production in a mountain environment, managing access to water is necessary to maintain stability. Ifugao practices follow what Richard O'Connor described as the "agro-cultural complex" in which agricultural practices, social systems, and political, historical, and, cultural changes are understood as interlocking processes (O'Connor 1995). In this paper, we focus on the relationship between Ifugao water and agricultural rituals with the synchronizing and sequencing of agricultural activities. Using the concept of self-organization, we argue that water and agricultural rituals in Ifugao are not only meant to reinforce community cohesion, they also synchronize the farming activities crucial to a terraced ecology. Utilizing the practice of puntunaan (a ritual plot or parcel in the centre of an agricultural district) and the institution of tomona (the ritual leader of an agricultural district) as a case study, we observed that disruptions in the water and rice rituals stimulated great change in Ifugao sociopolitical organization.
\end{abstract}

KEYWORDS: Water, Ifugao, rice terraces, the Philippines, upland people

\section{INTRODUCTION}

\オ ater evokes a Very powerful image among the Ifugao. It is a recurring theme in Ifugao oral traditions, particularly on the beginning and end of life (Barton 1946). The story of the Ifugao great flood symbolizes death, rebirth, and cleansing. As a people whose identity and subsistence is tied to their rice production system, this symbolism is translated into both sacred and practical realms of the Ifugao cosmos.

Water symbolism is also manifested in the Ifugao pantheon, which is made up of more than two thousand deities (Barton 1946; Lambrecht 1962), half of which are deities associated with rice agriculture rituals. The number of required rituals in each stage of Ifugao wet-rice production indicates the centrality of wet-rice in Ifugao culture. Indeed, wet-rice is the basis of customary Ifugao wealth and prestige. 
This paper looks at the agriculture-focused rituals in Ifugao and relates them to the ecology of the Ifugao agricultural system. In Acabado's previous work (Acabado 2012a), he described the Ifugao agricultural system as an "agro-cultural complex", a term popularized by O'Connor to describe the interlocking nature of agricultural practices, social systems, and political, historical, and, cultural change (O'Connor 1995). This is an apt term because for the Ifugao, wet-rice cultivation is part of a larger production system that includes swiddening and agroforestry. Following the work of Lansing (1991, 1993), the rituals associated with the Ifugao wet-rice production appear to have practical functions: they ensure availability of labour, minimizes conflicts by synchronizing field agricultural activities, and functions as reinforcement of Ifugao social organization.

In this article, we look at the concept of puntunaan (a ritual plot or parcel in the centre of an agricultural district), the tomona (the ritual leader of an agricultural district), and cooperative labour groups (uggbu and baddang) as important synchronizing strategies in the Ifugao agro-cultural system. We focus on the role of self-organization within a complex adaptive system framework as defining principles behind uggbu and baddang (Acabado [2013] initially employed the selforganization concept to define Ifugao social organization in an archaeological application). Based on four years of ethnographic work in the region, we argue that rituals and the control of water in Ifugao are tantamount to having enough food (rice) and a stable order (elite control). Without a strong water control system (managerial and infrastructural), the subsistence pattern and political economic system in Ifugao would collapse. Even with the rapid transformation of Ifugao political and economic systems, the link among water symbols, wet-rice rituals, and ecological applications remains strong (Acabado and Martin 2015).

\section{The Cordillera Lands of Wet-Rice Terraced Pondfields}

More than one million people now inhabit the Cordillera Central of northern Luzon (Philippines), a 20,000 sq. km region that now houses six provinces: Abra (Tingguian), Apayao (Isneg), Benguet (Kankanaey, Ibaloi), Ifugao (Ifugao), Kalinga (Kalinga, Isneg) and Mountain Province (Kankanaey) (Figure 1). Most inhabitants belong to one of these ethnolinguistic groups, though perhaps $10 \%$ of the Cordillera residents are Ilocano immigrants from the lowlands (De Raedt 1991: 355). Each of these ethnolinguistic groups has its own traditions, but despite these clear differences, the Spanish collectively called them the Ygorrotes (Igorots) soon after colonization in the $16^{\text {th }}$ century (Scott 1974: 2).

Dominant narratives in Philippine history consider the Ifugao "uncolonised", which has become a key feature of Ifugao identity (Scott 1969). The dichotomy between highland and lowland Philippines is also largely constructed in this historical narrative, which suggests that the northern highland Philippines resisted Spanish domination. Spanish cultural footprints in the province are scant, 


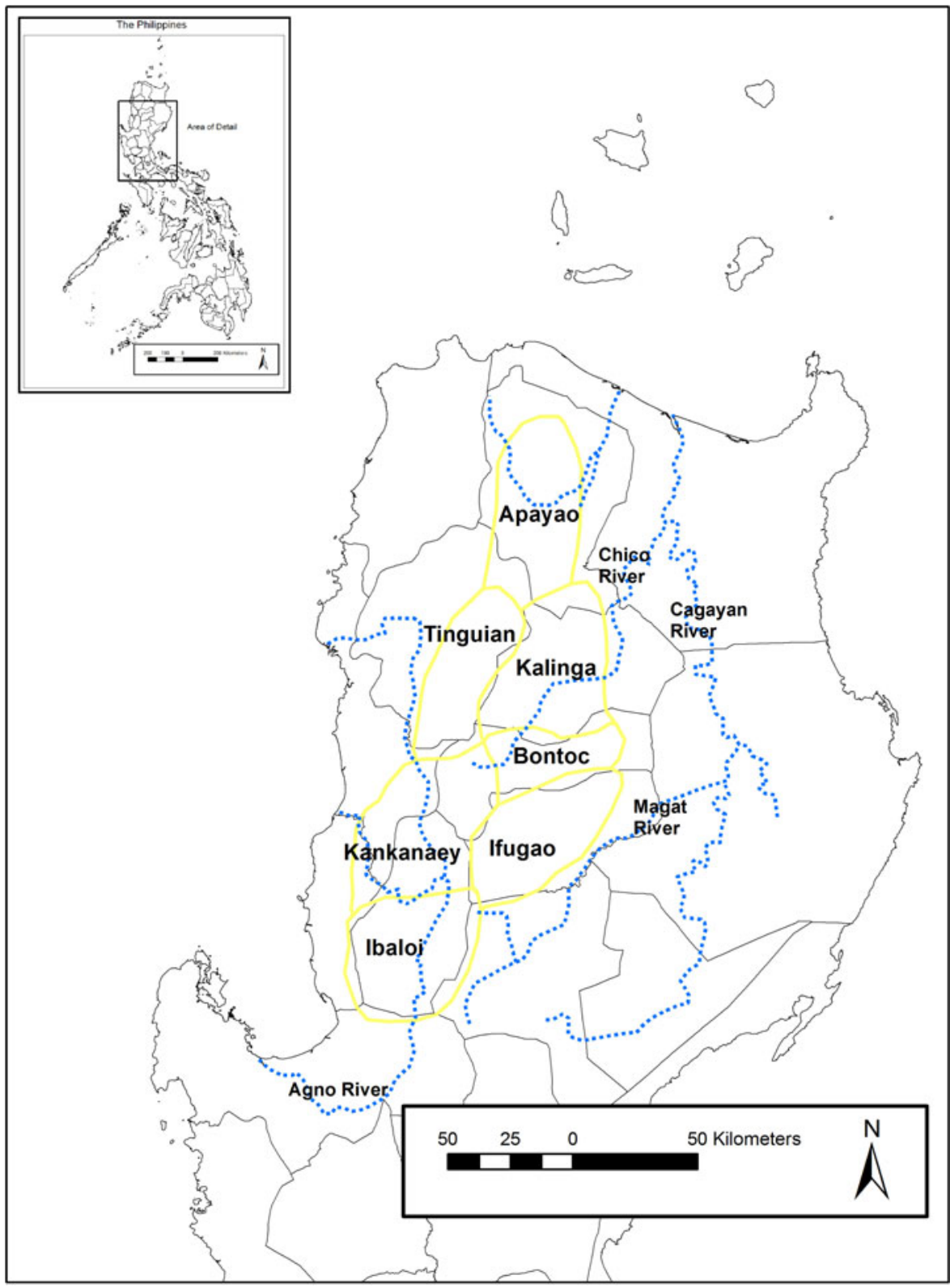

Figure 1. Major ethnolinguistic groups in the Philippine Cordilleras.

owing to the failure of the colonial power to establish a permanent presence in the region (Scott 1970, 1982). Nevertheless, major economic and political shifts in the highlands coincided with the arrival of the Spanish in the northern Philippines (Acabado 2016).

The recent findings of the Ifugao Archaeological Project (IAP) indicate that wet-rice varieties were introduced into the region after AD 1600 (Acabado 2009, 2015, 2016). Subsequent landscape modification (terraced wet-rice cultivation) also intensified between c. AD 1600 and AD 1800, suggesting increased 
demand for food, and a settlement pattern shift toward more densely populated villages.

Villages and hamlets were established close to major junctions of rivers and tributaries and these waterways identify relationships between villages. The flow of the river and its power seem to be an attractive force for people to establish their villages - adequate water pressure assures a sufficient water supply needed for their agricultural fields. More importantly, water serves to anchor intra- and inter-village relationships, as cooperation is needed to ensure the stability of the water flow. Indeed, disruptions to the water distribution system remain the major source of conflict in Ifugao.

Ifugao lies on the east of the Cordilleran divide, $17^{\circ}$ north of the equator. Settlements and human made features in the landscape lie 1,000-1,500 meters above sea level (Conklin 1980: 1). The year-round abundance of water (annual rainfall exceeds $3,000 \mathrm{~mm}$ ) and strong river flow makes wet-rice agriculture, even steep slopes, feasible with landscape modification. Irrigated ponded terraces and interspersed patches of woodlots occupy the gentler slopes often occurring with settlements in the lower portions of valleys (Conklin 1980: 1) (Figure 2).

The origins of the Ifugao people are a topic of scholarly debate. There are two poles in this debate, in the 'old history model' (from Barton 1919 and Beyer 1955) Ifugao settlement in the region began as early as 3000 years ago. A contrasting 'short history model', which we support (Acabado 2009, 2010a, $2010 \mathrm{~b}$ ), using recent archaeological evidence, argues instead that $16^{\text {th }}$ century Ifugao groups from the Magat Valley moved to the interior of the Cordillera to avoid the colonial aims of the Spanish. It is also likely that the ultimate origins

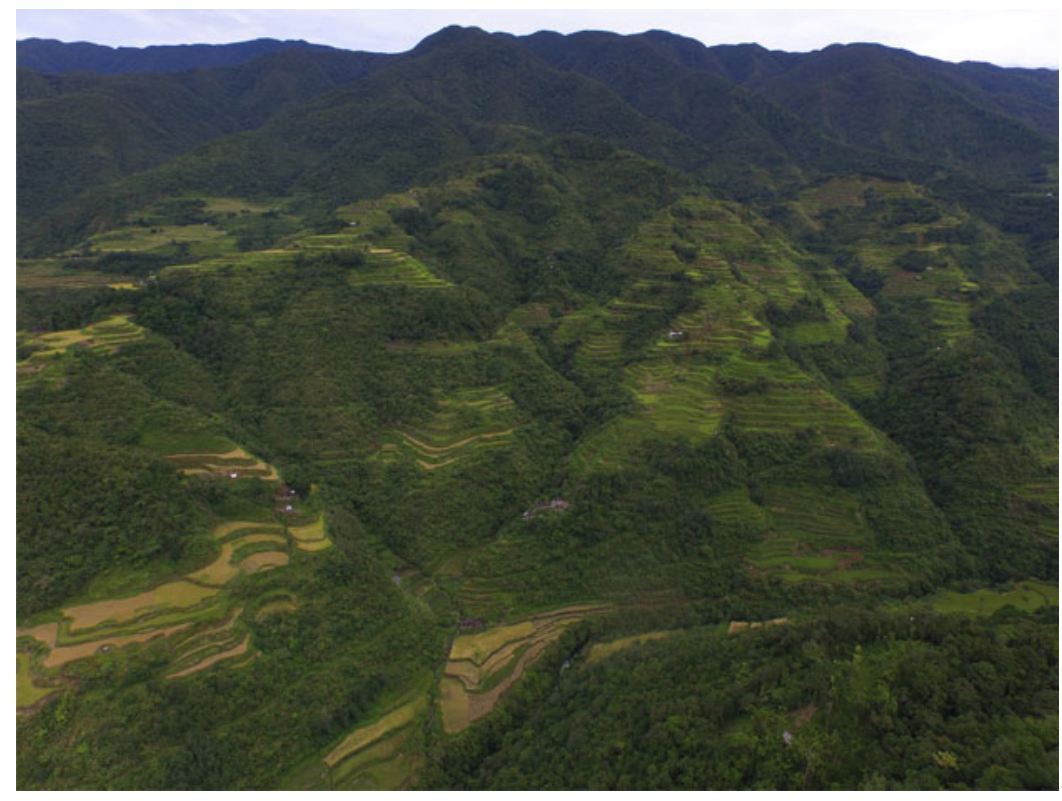

Figure 2. The Ifugao rice terraces. 
of the Ifugao is somewhere in the lowland valleys east of the Cordilleras, in present-day Isabela and Cagayan Provinces.

Ifugao migration to the mountains necessitated a shift in agro-cultural system as initial taro pondfields were transformed into wet-rice pondfields (Acabado 2012c; Peterson and Acabado 2015; Eusebio et al. 2015). The drastic increase in population that followed this migration would have stimulated the shift to a more labour-intensive agricultural production, and perhaps the adoption of pondfield-adapted rice varieties. The agricultural and irrigation systems in the highlands then, are fairly recent; so too might be the ethnogenesis of the Ifugao ethnolinguistic group.

\section{Water as Death, Rebirth, and Cleansing among the Ifugao}

Water symbolizes the beginning and the end in Ifugao mythology. The Ifugao cosmos is made up of six realms, with five of these located in the spirit world: Kabunyan (Skyworld), Dalom (Under World), Daya (Western World), Lagud (Eastern World) and Kadungayan (the spiritual place where the linnawa or souls of mortals go after death). The realm of humans is called Pugaw or the physical world, where mortals and other classes of spirits dwell. The origin myth of the Ifugao tells of a settlement founded by Bugan and Wigan. The basic premise of the Tuwali-Ifugao origin is similar across numerous versions of the myth. The myth may differ in detail depending on the narrator, but fundamental aspects of the myth remains more or less the same. The main characters of the narrative are Bugan and Kabigat, the children of Skyworld/Kabunyan deities. It is set between the Skyworld and the physical world, where humans live. The story begins as Bugan descends to the physical world from Skyworld through Kiyyangan (the gateway between mythological realms and the physical world). The reasons for this trip vary, some say it was to hunt and others say that it was to dig tubers. Whatever the reason may be, Bugan was in the human realm when Kabigat took advantage of his sister at night. A suspicious Bugan rubbed lime on her belly one night, only to find lime on her brother the following morning. After this, whether with the blessing of their parents or as a punishment, the two were married, and they settled in Kiyyangan, where they prospered.

After several generations, a great drought dried up all the rivers. The old men suggested digging in a riverbed to find the soul of the river. After three days of digging, a great spring gushed forth rapidly enough to kill many of the diggers. While the Ifugaos celebrated the waters, a storm came, the river kept rising, and the elders advised people to run for the mountains because the river gods were angry. Only two people made it to safety, a brother and sister, Balitoc and Bugan $^{1}$, who escaped to separate mountains, Amuyao and Kalawitan. Both had enough food on the summits, but only Bugan had fire. After six months, the

\footnotetext{
${ }^{1}$ In Ifugao mythology all females are named Bugan.
} 
waters receded; creating the rugged terrain that exists today. Balitoc reunited with his sister on Mt. Kalawitan and they settled in the valley. The sister later found herself with child and ran away in shame, following the course of the river. The god Maknongan, appearing as an old man, assured her that her shame had no foundation, since she and her brother would repopulate the world (Demetrio 1988). The great flood myth is shared by other Cordillera groups and seems to evoke the power of water.

Another important Ifugao ritual that involves water is associated with the "cleansing" property of water. The tobotbal di danum (call on the water) is an episode in several performances that invokes the gods of the Skyworld to wash away evil, malaise, and sorrow from the village, particularly during times of sickness and death. Villagers wash themselves by the river to either signify the start of the mourning period, or to end it.

Water is also used by the Ifugao to communicate with their deities. The Hapao people practice the punnuk, in which the Ihapao converge in the river to celebrate the end of a successful harvest season. Water games are played. Head ornaments made of dongla and straw scarecrows are sent downstream. The river is supposed to bring these to the deity, Binongbong, to inform him that harvest is over so he can lift the seasonal ban on certain ritually prohibited foods.

The water and agriculture rituals in Ifugao appear to be a cultural strategy to regulate activities that are detrimental to community cooperation. In this sense, the sacred and the secular intersect in Ifugao systems of water management and agricultural production.

\section{Subsistence Strategies}

The Ifugao are agriculturalists who have cultivated wet-rice for at least 300 years. Their agro-cultural system (Acabado 2012) exhibits a complementary strategy combining the management of private forests (muyong), swidden cultivation of sweet potatoes (uma), pond-field cultivation of rice (payo), inter-cropping of many secondary domesticates (i.e. sweet potatoes, potatoes, cabbage, and other cash crops), and the raising of pigs, chickens, and other forms of livestock (Conklin 1980: 36).

The agricultural pattern of the Ifugao is complex. Ecological, social, and cultural factors, including indigenous knowledge of how these factors are linked to each other, and efficient utility affects this pattern. Within a particular watershed, several types of land use categories comprise the agricultural system. There are two types of forest cover: Inalahan/hinuob which are upslope communal forest often composed of open access communal areas; and muyong/pinugo which are privately owned woodlots and managed with definite boundaries. There is also uma (swidden) which is unirrigated slopeland cultivated with root crops, 
usually sweet potatoes; latangan (house terrace) located on a residential site; $n a$ ilid (drained field) a levelled terraced area for cultivation of dry crops such as sweet potatoes and legumes; and payo (irrigated rice field) situated on levelled, terraced farmland, bunded to retain water. Figure 3 illustrates the suite of agricultural strategies in Ifugao, while Table 1 (below) summarizes the land use categories of the Ifugao.

An important aspect of Ifugao agricultural terrace ecology and maintenance is the land use category of muyong/pinugo, or privately owned woodlots. These woodlots serve as the watershed of a particular terrace system and are invaluable for terraces whose primary source of water are the springs located in these woodlots. Hydrologic studies (Hamilton and King 1983; Bruijnzeel 1990; Saberwal 1997) in the last three decades suggest that heavy forest cover actually result in more usage of groundwater. Yet, it remains the case that these woodlots protect low-lying fields from runoffs and erosion, maintain a supply of surface and irrigation water through cloud-interception, stabilize relative humidity, and improve soil's nutrients and physical and chemical properties (Conklin 1980). Indeed, increases in logging activities in the vicinity of Banaue in the early 1980s accelerated runoffs and evapotranspiration, intensifying water shortage during the dry season (Eder 1982).

\section{Wet-Rice Cultivation}

In past studies, anthropologists primarily focused on intensive systems of cultivation to describe the relationship of subsistence patterns to social complexity (Adams 1966; Hunt and Hunt 1971; Morrison 1994). The central management of large irrigation systems, and intensification associated with these systems, has been seen as the stimulus for the emergence of social complexity. However, there are a significant number of irrigation systems run by local community organizations in Southeast Asia and very little attention has been paid to

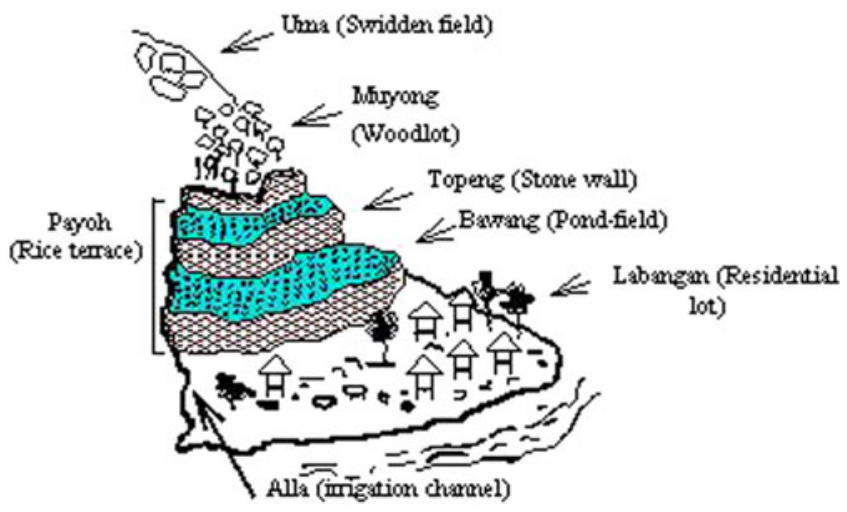

Figure 3. Profile of an Ifugao terrace system (from Acabado 2010: 83). 
Table 1. Land use categories of the Ifugao (adapted from Conklin 1980:7-8).

\begin{tabular}{|c|c|c|}
\hline \multicolumn{3}{|r|}{ Land Use } \\
\hline $\begin{array}{l}\text { Local } \\
\text { Term }\end{array}$ & $\begin{array}{l}\text { Land } \\
\text { Usage }\end{array}$ & Description \\
\hline Mapulun & Grassland & $\begin{array}{l}\text { exposed ridge and slopeland; untilled; with low herbaceous } \\
\text { grasses; communal (in any given region); unmanaged; } \\
\text { minimal value; source of roof thatch, game; not cultivated } \\
\text { without new irrigation sources; usually far from densely } \\
\text { inhabited areas }\end{array}$ \\
\hline 'Inalāhan & Forest & $\begin{array}{l}\text { slopeland; undisturbed soil, naturally woody cover; com- } \\
\text { munal (for residents of same watershed region); un- } \\
\text { managed; source of firewood, forest products, game. }\end{array}$ \\
\hline Mabilāu & Caneland & $\begin{array}{l}\text { (high grassland, cane grassland, secondary growth Miscan- } \\
\text { thus association): mostly slopeland, unworked soil, } \\
\text { covered with various stages of second-growth herbaceous } \\
\text { and ligneous vegetation dominated by dense clumps of } \\
\text { tall canegrass; some protection and management (cane- } \\
\text { grass much used for construction, fencing, etc.). }\end{array}$ \\
\hline Pinuḡ̄ & Woodlot & $\begin{array}{l}\text { slopeland; unturned soil; covered with high tree growth } \\
\text { (timber and fruit trees, climbing rattans, etc.); privately } \\
\text { owned and managed (some planting of tree, vine, and } \\
\text { bamboo types), with definite boundaries; valued for } \\
\text { timber, other products, and protection of lower farmland } \\
\text { from runoff and erosion. }\end{array}$ \\
\hline Hābal & Swidden & $\begin{array}{l}\text { slopeland, cultivated and often contour-ridges" heavily } \\
\text { planted with sweet potatoes; moderately intercropped } \\
\text { (including rice below } 600-700 \mathrm{~m} \text { ); discrete temporary } \\
\text { boundaries for cultivation period of several years. }\end{array}$ \\
\hline Latāngan & $\begin{array}{l}\text { House } \\
\text { Terrace }\end{array}$ & $\begin{array}{l}\text { leveled terrace land; surface smooth or paved but not tilled; } \\
\text { primarily house and granary yards; workspace for grain } \\
\text { drying, and so forth; discrete, often fenced or walled. }\end{array}$ \\
\hline Nà̄lid & $\begin{array}{c}\text { Drained } \\
\text { Field }\end{array}$ & $\begin{array}{l}\text { leveled terrace land, surface ditched and mounded (usually } \\
\text { in cross-contoured fashion) for cultivation and drainage } \\
\text { of dry crops such as sweet potatoes, legumes; discrete } \\
\text { boundaries, privately owned; kept in this temporary state } \\
\text { for a minimum number of seasons before shifting to } \\
\text { permanent form of terrace use. }\end{array}$ \\
\hline Payo & Pond Field & $\begin{array}{l}\text { leveled, terraced farmland, bunded to retain water for } \\
\text { shallow inundation of artificial soil; carefully maintained } \\
\text { for cultivation of wet-field rice, taro, and other crops; } \\
\text { privately owned, discrete units, permanent stone } \\
\text { markers. }\end{array}$ \\
\hline
\end{tabular}

these systems. The result is a significant gap in scholarly knowledge (Barker and Molle 2002).

Examples of these community-based irrigation systems include densely populated lowland-Philippine areas of Ilocos and less densely populated province 
of Isabela that practice the zanjera system. Zanjera is a cooperative system of agricultural management developed in the northern Philippines (Coward 1979). It involves the organization of water allocations, maintenance of common agricultural structures (i.e. irrigation channels and ditches), as well as a management system for conflict resolution. In other words, a zanjera is a large, participatory, and communal irrigation system devoid of large-scale state intervention. Currently, the National Irrigation Administration of the Philippines manages dams and water reservoirs. The zanjeras, in contrast, operate canals and water distribution.

Henry Lewis provides a description of the zanjera irrigation societies in the northern Philippine provinces of Ilocos and Isabela (Lewis 1971). Lewis writes that the Philippine zanjera system developed in the province of Ilocos, historically a densely populated region in the country. After the Second World War, the Philippine government sponsored migration to less-densely populated areas in the country, similar to transmigrasi program in Indonesia. It was during this time that Ilocano migrants settled in the province of Isabela. These Ilocano migrants were originally members of community-organized irrigation associations or zanjeras. However, the migrants did not form local zanjera associations in their newly settled place. Lewis suggested that differences in the resource base between Ilocos and Isabela inhibited the formation of zanjera associations. The easily available water source in Isabela from the Cagayan River and its tributaries, as well as lower population densities in the province eliminated the need for community management of agricultural resources. The rapid population growth in Isabela in the last four decades, however, necessitated the establishment of irrigation cooperatives in the province, albeit under the direct supervision of the state's Department of Agriculture.

In Ifugao, we do not see formal irrigation organization such as the zanjera, although there is a customary cooperative system (uggbu or baddang) that functions as reciprocal labour. Most rice fields in Ifugao share a common water source, as such, cooperation among fields sharing a water source is apparent. The need for this cooperation is most emphasized in areas of intense population pressure or limited water supplies, or both. In these places, the organization of community labour and management is essential to gain access to and share water, and to minimize conflicts (Tang 1992; Ostrom 1992). Similar to the examples cited previously, the Ifugao case provides an illustration of a communal cooperative system, as necessitated by topographic/environmental limitations.

\section{Complex Adaptive Systems and Self-Organization}

The nature of Ifugao social organization counters Karl Wittfogel's hydraulic theory that the organization of complex irrigation systems requires a strong centralized state (1955), while closely aligning with J. Stephen Lansing's (1991) wellknown Balinese case study. Although the social organization of the Ifugao differs remarkably from the Balinese, the intensive agricultural system and management 
of irrigation are similar. As opposed to the Wittfogelian model, both the Balinese and the Ifugao case studies do not seem to have a centralized irrigation management, at least in the ethnographic present. In fact, both systems support a model that points to the emergence of self-organization (Kauffman 1993, 1995; Scarborough et al. 2000; Schoenfelder 2000).

Ifugao methods for organizing their agricultural production and political economy might best be understood as a Complex Adaptive System (CAS). Anthropologists employ the term Complex Adaptive System as a nonlinear model of culture change that questions the hierarchical positions of certain actors. Holland (1995: 4-6) describes CAS as a dynamic network of many agents that may represent cells, species, individuals, firms, nations, and so on acting in parallel, constantly acting and reacting to what the other agents are doing. The control of a CAS tends to be highly dispersed and decentralized. If coherent behaviour arises in the system, it is due to competition and cooperation among the agents themselves. The overall behaviour of the system is the result of a huge number of decisions made every moment by many individual agents. As such, CAS models change through a consideration of agency and human decisionmaking. The most notable use of CAS in anthropology is as a model for the emergence of order within the population level. Processes once assumed that result from chance at individual level, are now viewed as predictable at the societal level (Lansing 2003: 185).

John Schoenfelder describes Lansing's (1991) work in Bali as a model wherein self-organization emerged due to a "need to balance multiple agroecological concerns in a crowded landscape of terraced rice fields that could feasibly have been responsible for the emergence of Bali's yield-enhancing autonomous 'complex adaptive system' of agriculture-managing water temple congregations" (Schoenfelder 2003: xv). This is comparable to Ifugao terrace systems where the expansion of terraced fields placed pressure on land and water and resulted in pest increase. These pressures provided the impetus for villages/settlements whose fields are contiguous to share a water source and work together to pool resources. This process corresponds to a "selforganizing model"; a term used by complexity theorists to describe the ways that order is generated by events within the system and not by outside influences (Kauffman 1993). Park (1992) and Lansing and Kremer (1993) have applied the CAS and self-organizing in their studies of political stratification and irrigation management.

Utilizing the self-organizing model, we suggest that the local irrigation management of the Ifugao is a result of the need for cooperation to control water and land distribution as well as pest management. The synchronization of farming activities - headed by the tomona and signalled by rituals - substantiates this assertion. Hamlets within a watershed/agricultural district form an informal group (baddang) that is tasked with agricultural-related activities. Similar to Bali, rituals 
and function-specific informal groups may have been a result of self-organizing processes.

Self-organization in Ifugao must be directly associated with the synchronization of agricultural activities and its effects on productivity, pest management, and water distribution. We hypothesize that the role of the tomona and the synchronization of activities is directed towards pest management, labour availability, and irrigation distribution; and that these processes are analogous to the Balinese subak system (Lansing 1991; Schoenfelder 2003).

\section{Water Management in Ifugao Culture}

Locations for Ifugao rice terrace construction are based on the availability of freshwater springs. Water flow trumps slope angle in decisions on terrace locations, and Ifugao farmers cut terraces into slopes of more than a $40^{\circ}$ gradient (Acabado 2012a: 510-516). Terrace construction begins with excavating an irrigation channel. Expansion of the terraced construction uses existing irrigation structures, and involves a payment (adang), usually in pigs, to the original builder/ owner of the channel. It also requires that all canal users consent to channel maintenance and repair.

The Ifugao water management system is a community-based irrigation system where farmers sharing a common irrigation source coordinate their activities and share in the maintenance of the irrigation infrastructure. The system also illustrates the complementary nature of swidden fields, forest cover, and irrigated terraces (Acabado 2013a). Swidden fields and communal ${ }^{2}$ forests are considered commons property, while irrigated terraces and forest cover on top of a terrace system is considered private property. Irrigation infrastructure is a commons property.

Most anthropologists agree that agrarian-focused water systems entail some form of management, but disagree over the degree of organizational complexity in traditional systems (Lansing 1999; Earle and Doyel 2008; cf. Kolata 1991). Conflict mediation and preventing system disruptions are clearly the greatest challenges in water management; how these conflicts are resolved depends on the nature of organizational complexity. Water management systems require cooperation and compromise, which are often structured through law. The more flexible the rules of access and usage, the greater the resilience of the system (Scarborough 2000: 3).

Water management demands are interrelated to the structure of Ifugao social life, which as Conklin describes (1980: 110), centres on the local community, the puntunaan (ritual plot), and the tomona (the ritual leader) (see Figure 4 below). The tomona must synchronize agricultural activities, manage available labour,

\footnotetext{
${ }^{2}$ The concept of communal in Ifugao denotes village ownership. Thus, access to resources on communal forests is limited to village members to whom the forest is associated, and non-community members are strictly excluded.
} 


\section{Agricultural Districts and Ritual Plots}

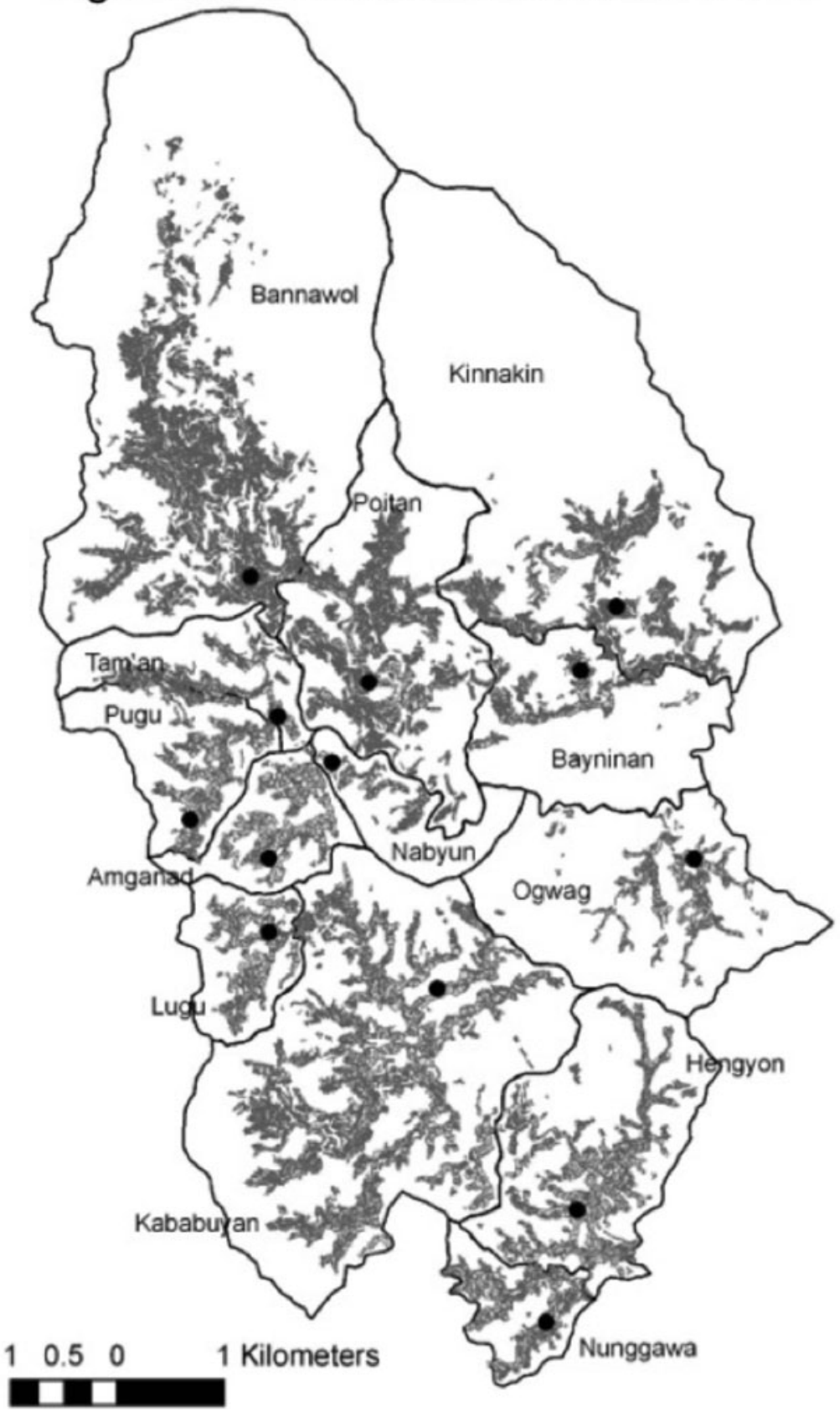

Figure 4. Agricultural Districts (himpuntunaan) and the locations of ritual plots (puntunaan) in North Central Cordillera about here.

control water use and pest management, and sponsor ritual activities. The customary communal workgroup (uggbu and baddang) forms the foundation of this work. The puntunaan plot is customarily the first to be cleaned, planted, transplanted, harvested, and is where other activities related to terrace 
agriculture take place. Once a tomona has performed the ritual (Table 2) and started a particular agricultural activity, other members of the himpuntunaan (agricultural district) can start to work on their fields; however, larger fields which are owned by the elite (or kadangyan) will be worked on first because of labour requirements. Similar to the Balinese subak system (Lansing 1991), this synchronization has something to do with water and pest control, labour distribution, and productivity. Although the locations of these puntunaan do not appear to be important in controlling the aspects mentioned above, the rituals that signal the start of every agricultural activity provide the mechanism where the Ifugao cope with the problems associated with terrace agriculture.

\section{IMPLICATIONS}

The ecology of the Ifugao landscape and the needs of wet-rice agriculture require a strategy that minimizes conflict, particularly access to water. In our work in Ifugao, it appears that there is a link between the tomona system and the

Table 2. Tomona-sponsored Ifugao rituals associated with rice production and consumption in Banaue, Ifugao (adapted from Pagada 2006).

\begin{tabular}{|c|c|}
\hline Ritual & Purpose \\
\hline Lawang & Ritual conducted after field seed bed preparation \\
\hline Loa-ah & Ritual performed before sowing rice \\
\hline Opdah & Follow-up for rice seed ritual \\
\hline $\begin{array}{l}\text { Tinongur or } \\
\text { boge }\end{array}$ & Transplanting ritual \\
\hline Toong & Ritual for newly built rice field \\
\hline Ulpi & Thanksgiving ritual after all rice fields are planted \\
\hline Hagophop & Second thanksgiving ritual sponsored by kadangyan (elite) \\
\hline Alup or hanglag & Pre-harvest ritual \\
\hline Lodah & $\begin{array}{l}\text { Rice harvest ritual - performed when a person is working on another } \\
\text { person's field }\end{array}$ \\
\hline Topdad & $\begin{array}{l}\text { Rice harvest ritual sponsored by the tomona to formally start rice } \\
\text { harvesting season }\end{array}$ \\
\hline Pumbuto-an & Harvest ritual \\
\hline Torchag & $\begin{array}{l}\text { Ritual conducted before placing the bulol (rice guardian) rice in the } \\
\text { granary }\end{array}$ \\
\hline Hu-ap & Closing of the punham-an (sacred box used in rituals) \\
\hline Ubaya & Ritual for driving away evil spirits \\
\hline Luat & Ritual conducted at the end of harvest season \\
\hline Apoy & Ritual before consumption of stored rice \\
\hline Bahle & Kadangyan-sponsored ritual \\
\hline Tamol & Laying of herbs in the fields meant to kill worms and other pests \\
\hline Gito & $\begin{array}{l}\text { Ritual performed for weather disturbance (i.e. thunderstorm) during } \\
\text { the agricultural period }\end{array}$ \\
\hline
\end{tabular}


scheduling of agricultural activities, a system that Acabado (2013) described in his previous research as self-organization. As a self-organizing system, the practice of puntunaan and tomona applies directly to the ecology of Ifugao agricultural terraces. The Ifugao acquire water for their fields from streams, springs, and rivers. There are no dams or irrigation tanks to store water. However, the rivers that they tap into have sufficient water to supply most of the fields. Terraces fed by streams and springs are different. They rely on the seasonality of water flow and the locations of terraces and relative optimality for rice production is associated with their value. Tapping rivers and streams requires the construction of kilometreslong irrigation channels, beginning at a weir upstream to divert part of the flow into irrigation channels. These irrigation channels, in turn, supply water to terrace systems. There are also irrigation channels that are supplied by all three water sources: rivers, streams, and springs.

According to Lansing (1991: 39), to appreciate the level of precision required for the system to work, it is necessary to understand the basic dynamics of the paddy ecosystem. This includes knowledge about nutrient cycles that characterize the wet and dry nature of paddy fields. The cyclical nature of paddy-rice cultivation implies a need for synchronization and cooperation among farmers.

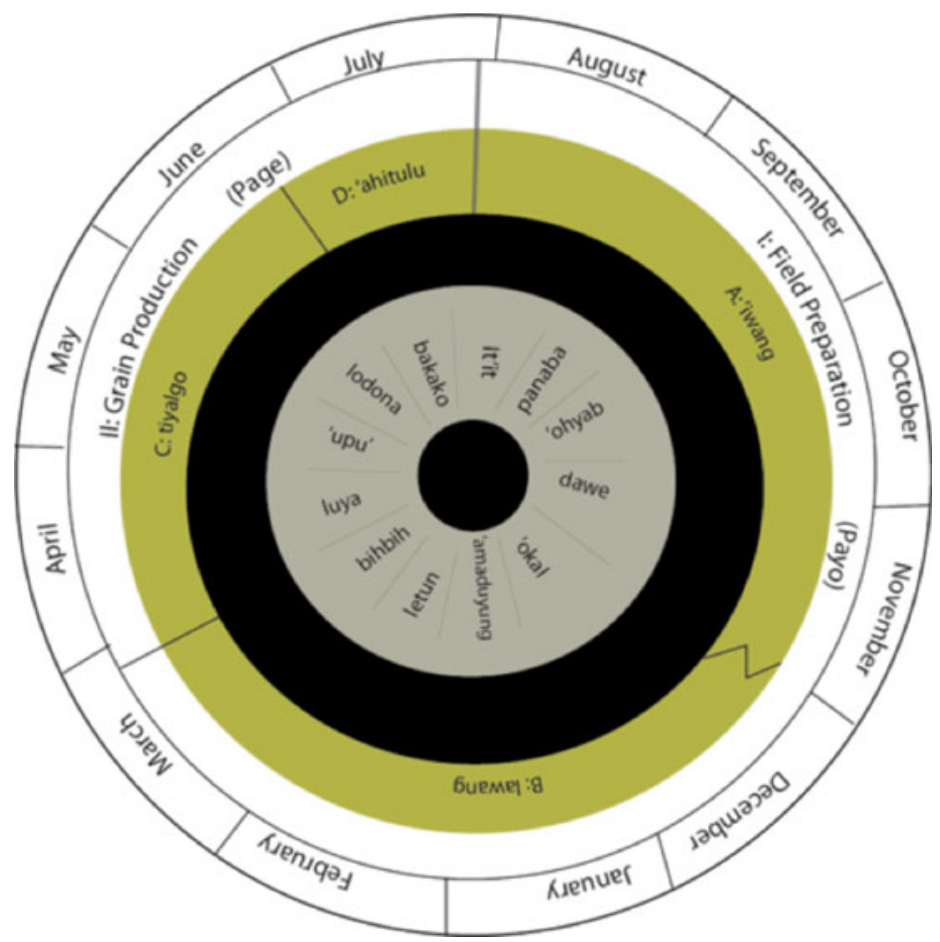

Figure 5. The Ifugao agricultural calendar (illustrated with the Gregorian calendar months [outer ring]; major Ifugao agricultural activities; agricultural seasons [third ring from the outer-most ring]; and, Ifugao lunar months [spoked inner ring]) (adapted from Conklin 1980). 
Mutual support among farmers within a terrace system, thus, is paramount to the effectiveness of drying or flooding fields as a method of pest control. A single farmer's attempt to reduce pests on a field without the coordination of other farmers would be futile because pests will simply migrate from one field to another. However, when all fields in the system are burned or flooded in coordination, the pest population is reduced. The synchronization of activities make both kinds of fallow (burnt or flooded) effective for reducing rice pests. Just as individual farmers manage their paddies by controlling the flow of water, so do larger social groups control pest cycles by synchronizing agricultural activities.

The synchronization is evident in the concept of puntunaan and tomona. Although more work is necessary for a deeper understanding of these processes, the main principle revolves around organization and ecology of rice production. Self-organization seems to have emerged amidst the need to maintain Ifugao societies. Cooperation, rather than centralized control, is vital in the endurance of Ifugao societies.

Acabado and Martin (2015) reports that as of July 2014, only three himpuntunaan still practice the tomona system: Hapao, Batad, and Hengyon. According to Ifugao elders, all himpuntunaan practiced puntunaan as late as the 1970s. These three himpuntunaan appear to have enough local labour force to work in their fields while other himpuntunaan import field workers from other districts during planting and harvesting season. The sequencing and synchronizing feature of the tomona rituals enable local farmers in these three villages to ensure enough labour during peak agricultural activities. The power of the tomona, however, is waning. In 2014, during our fieldwork in Hapao we documented the harvesting of a particular field that lasted for three days. Hapao farmers stated that in past years, it would have taken them just a day to complete the activity. They lamented the breakdown in the tomona system and the decreasing influence of the uggbu and baddang.

In Kiangan, Ifugao, the practice of puntunaan and tomona have been abandoned for generations, we have observed a large-scale importation of labour and a total breakdown of the Ifugao agro-cultural system. When the tomona disappeared, rituals were abandoned. This was followed by the introduction of commercial rice varieties (Table 2) that modified the rice cycle. There was no synchronization of agricultural activities resulting in cross infestations and the introduction of new types of pests such as the golden snail. Chemical pesticides and synthetic fertilizers followed suit. Field workers were imported from other towns, even from the lowlands. A rise in community conflicts also increased because of uncoordinated water use.

The rapid assimilation of the Ifugao in the market economy and state politics has also spelled danger to the Ifugao social and agricultural systems (Acabado and Martin 2015). Reciprocal labour is disappearing and state-sponsored politicians are taking over the authority of the tomona. As an example, the National Irrigation Administration, a state agency, has taken the lead in the maintenance of 
irrigation systems in Ifugao. This activity is associated with funds provided by the national government. Although it is still the farmers who carry out the repairs and maintenance of the system, they are paid in cash by the project. This has immense implication for the sustainability of the Ifugao agricultural system because it signals the erosion of the basic socio-political dynamic that long regulated the social and ecological fabric of Ifugao life. As a case in point, the National Irrigation Administration sponsored a project to convert the Ifugao irrigation system into concrete structures in Hapao, Hungduan in 2003 (Figure 6). The principle behind the structural change was conceived by engineers who thought that concrete irrigation channels require less maintenance than earthen structures. Most of the workers who were hired to help with the constructions were local farmers. They were paid monetarily, based on the prevailing wage standards. However, a few weeks after the completion of the project, a typhoon caused several small landslides that buried segments of the system. The local farmers could not muster enough workers because they preferred to wait for the national government to pay them to repair the damaged portions of the system. In the summer of 2014, the system was still inoperable.

Water distribution has also become a source of conflict among Ifugao farmers. Previously, the customary Ifugao socio-political organization has controlled the synchronization of water distribution among fields sharing a common water source, but because of the erosion of the cooperative principle, it is now normal to see farmers guarding their irrigation channels with guns.

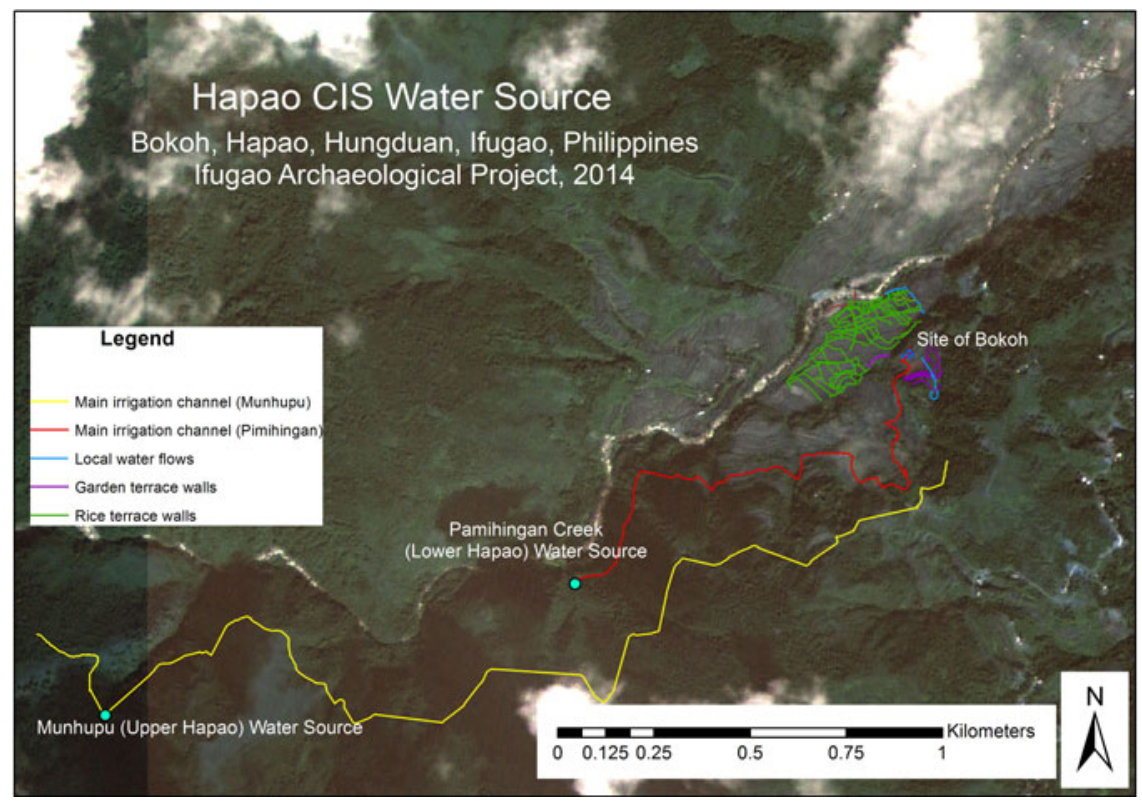

Figure 6. The Hapao Terrace Cluster. 
Table 3. Known and named commercial and local rice varieties cultivated in Kiangan and Hungduan Municipalities (from Acabado and Martin 2015).

\begin{tabular}{ll}
\hline Commercial Varieties & Tinawon Varieties \\
\hline 52 & Binogon \\
82 & Botnol \\
222 & Iggamay \\
C-12 & Imbannig \\
C-2 & Imbuukan \\
C-4 & Madduli \\
C-4 red & Mayawyaw \\
Diamond & \\
Halaylay & \\
Ingaspar & \\
Ingaspi & \\
Korean & \\
Migapas & \\
Minmis & \\
Mukoz & \\
Mulmug & \\
Munoz & \\
NSCI-208 & \\
Pakulsa & \\
Oakland & \\
Oklan & \\
Oklan Minaangan & \\
Pangasinan variety & \\
PJ-27 & \\
PJ-7 & \\
RC-218 & \\
RI-152 & \\
RI-238 & \\
Romelia & \\
RP 224 & \\
Super 60 & \\
Taiwan & \\
Thunder & \\
\hline
\end{tabular}

\section{Conclusion: Water is Sacred, Water is Power, WATER IS LIFE}

Water is key to the economic, political, and spiritual realms of the Ifugao. Water is sacred as it is a recurring theme in their oral tradition. These water symbolisms are also demonstrated in their practical existence where they comprise the organizing force behind Ifugao politics and economics. Thus, water links the sacred and the secular.

For the Ifugao, the saying that water is life applies literally and figuratively to their history and heritage. The economic value of and importance of water to 
subsistence activities in Ifugao life are immense because water anchors their economic, social, and spiritual existence. Recently, the importance of water has been subsumed by the centrality of rice in Ifugao culture and history, but disruptions in the Ifugao water management system are causing major fractures in the Ifugao world.

The assimilation of the Ifugao into the larger Philippine society has lasting repercussions on their way of life. Rice production has become an economic activity rather than an anchor to their identity and heritage. These changes indicate that, currently, the primary goal of producing rice in Ifugao is to gain monetarily which is stimulating transformations in the culture. To give just one example, this has resulted in a shift in gender roles. Men have taken over the responsibility of planting and harvesting. As a consequence, women as repositories of customary Ifugao agricultural knowledge will likely fade in a generation. The terraces have become a source of income, and thus, we can expect a shift in the social institutions that will come to govern the emerging agricultural system in the region.

\section{Acknowledgements}

We thank Dr. Lindsay Lloyd-Smith and Dr. Eric Tagliacozzo for organizing the Symposium, Water in Southeast Asia: Navigating Contradictions, where a version of this paper was presented with Dr. Miriam Stark as a co-presenter. We are also indebted to two peer reviewers who provided valuable comments. Funding for the Ifugao research was provided by an NSF Dissertation Improvement Grant (BCS 07-04008), a Luce Foundation/ ACLS Dissertation Fellowship, NGS-CRE (NGS 9029-12), and a National Museum of the Philippines Research Grant. The argument for a self-organizing system in Ifugao was initially articulated by Stephen Acabado in "Defining Ifugao social organization: "House", field, and self-organizing principles in the northern Philippines". Asian Perspectives 52(2), 161-189. Portions of this paper appeared in Acabado 2013 and Acabado and Martin 2015.

\section{References}

Acabado, Stephen B. 2016. The archaeology of pericolonialism: Responses of the "unconquered" to Spanish conquest and colonialism in Ifugao, Philippines. International Journal of Historical Archaeology, DOI: 10.1007/s10761-016-0342-9.

Acabado, Stephen B. 2015. Antiquity, Archaeological Processes, and Highland Adaptation: The Ifugao Rice Terraces. Quezon City: Ateneo de Manila University Press.

Acabado, Stephen B. 2013a. Defining Ifugao social organization: "House", field, and self-organizing principles in the northern Philippines. Asian Perspectives 52(2), 161-189.

Acabado, Stephen B. 2012a. The Ifugao agricultural landscapes: Complementary systems and the intensification debate. Journal of Southeast Asian Studies 43(3), 500-522.

Acabado, Stephen B. 2012b. The Old Kiyyangan excavations: A report submitted to the National Museum of the Philippines. 
Acabado, Stephen B. 2012c. Taro before rice terraces: Implications of radiocarbon determinations, ethnohistoric reconstructions, and ethnography in dating the Ifugao terraces. In Matthew Spriggs, David Addison, and Peter J. Matthews (eds.), Irrigated Taro (Colocassia Esculenta) in the Indo-Pacific: Biological and Historical Perspectives. Senri Ethnological Studies. Osaka: National Museum of Ethnology.

Acabado, Stephen B. 2010a. The Archaeology of the Ifugao Agricultural Terraces: Antiquity and Social Organization. (Unpublished PhD thesis). University of Hawai'i at Manoa, Honolulu.

Acabado, Stephen B. 2010b. Landscapes and the archaeology of the Ifugao agricultural terraces: Establishing antiquity and social organization. Hukay: Journal for Archaeological Research in Asia and the Pacific 15, 31-61.

Acabado, Stephen B. 2009. A Bayesian approach to dating agricultural terraces: A case from the Philippines. Antiquity 83, 801-814.

Acabado, Stephen and Marlon Martin. 2015. Between pragmatism and cultural context: Continuity and change in Ifugao wet-rice agriculture. In Water and Heritage: Material, Conceptual and Spiritual Connections. W. Willems and H. van Schaik (eds.), pp. 275-297. Leiden: Sidestone Press Academic.

Adams, Robert Mc. 1966. The Evolution of Urban Society: Early Mesopotamia and Prehispanic Mexico. Piscataway, NJ.: Transaction Publishers.

Barker, Randolph and Froncois Molle. 2002. Perspectives on Asian irrigation. Paper presented at the Conference on Asian Irrigation in Transition - Responding to the challenges ahead, 22-23 Apr. 2002 Workshop. Bangkok: Asian Institute of Technology.

Barton, Roy F. 1919. Ifugao law. University of California Publications in American Archaeology and Ethnology 15, 1-186.

Barton, Roy F. 1946. The religion of the Ifugaos. American Anthropologist, 48(2, 4): 3-219.

Barton, Roy F. 1955. Mythology of the Ifugaos. Philadelphia: American Folklore Society.

Beyer, H. Otley. 1955. The Origins and History of the Philippine Rice Terraces. Proceedings of the Eight Pacific Science Congress, 1953. Quezon City: National Research Council of the Philippines.

Bruijnzeel, Leendert Adriaan 1990. Hydrology of Moist Tropical Forests and Effects of Conversion: A State of Knowledge Review. Amsterdam: National Committee of the Netherlands for the International Hydrological Programme of Unesco.

Conklin, Harold C. 1980. Ethnographic Atlas of Ifugao. New Haven: Yale University Press.

Coward, Walter. 1979. Principles of social organization in an indigenous irrigation system. Human Organization 38(1), 28-36.

Demetrio, Francisco, 1988. The flood motif and the symbolism of rebirth in Filipino mythology. In The Flood Myth, Alan Dundes (ed.), pp. 261-265. Berkeley and London: University of California Press.

DeRaedt, J. 1991. Similarities and differences in lifestyles in the central Cordillera of northern Luzon, Philippines. In Profiles in Cultural Evolution, A. Terry Rambo and Kathleen Gillogly (eds.), pp. 353-372. Anthropological Papers No. 85. Ann Arbor: Museum of Anthropology, University of Michigan.

Earle, Timothy and David Doyel. 2008. The engineered landscapes of irrigation. In Economies and Transformation of Landscapes, C. Pool and L. Cligget (eds.), pp. 19-46. Lanham, MD: Altamira Press.

Eder, James. 1982. No water in the terraces: Agricultural stagnation and social change at Banaue, Ifugao. Philippine Quarterly of Culture and Society 10, 101-116. 
Eusebio, Michelle, Ma. Jasminda Ceron, Stephen B. Acabado, and John Krigbaum. 2015. Rice pots or not? Exploring ancient Ifugao foodways through organic residue analysis and paleoethnobotany. National Museum Journal of Cultural Heritage 1, 11-20.

Hamilton, Lawrence S. and Peter N. King. 1983. Tropical Forested Watersheds: Hydrologic And Soils Response to Major Uses or Conversions. Boulder: Westview Press.

Holland, John H. 1995. Hidden Order. Reading, MA: Addison-Wesley.

Hunt, Eva, and Robert C. Hunt. 1971. Irrigation, conflict, and politics: A Mexican case. In Irrigation's impact on society, ed. T. Downing and M. Gibson (eds.), pp. 129-157. Tucson: University of Arizona, Press.

Kauffman, Stuart A. 1993. The origins of order: Self organization and selection in evolution. Oxford: Oxford University Press.

Lansing, J. Stephen. 1991. Priests and Programmers: Technologies of Power in the Engineered Landscape of Bali. Princeton, NJ: Princeton University Press.

Lansing, J. Stephen. 1999. Anti-chaos, common property and the emergence of cooperation. In Dynamics in Human and Primate Societies: Agent-Based Modelling of Social and Spatial Processes. Timothy Kohler and George Gumerman (eds.), pp. 207-224. Santa Fe Institute and Oxford University Press.

Lansing, J. Stephen. 2003. Complex adaptive systems. Annual Review of Anthropology, 183-204.

Lansing, J. Stephen and James N. Kremer. 1993. Emergent properties of Balinese water temple networks: Coadaptation on a rugged fitness landscape of Bali. American Anthropologist 95, 97-114.

Lambrecht, Francis. 1962. The religion of the Ifugao. Philippine Sociological Review, 33-40.

Lewis, Henry. 1971. Ilocano Farmers: A Comparative Study Of Two Philippine Barrios. Honolulu: University of Hawaii.

Kolata, A. 1991. The technology and organization of agricultural production in the Tiwanaku state. Latin American Antiquity, 99-125.

Morrison, Kathleen. 1994. The intensification of production: Archaeological approaches. Journal of Archaeological Method and Theory 1, 111-60.

O'Connor, Richard. 1995. Agricultural change and ethnic succession in Southeast Asian states: A case for regional anthropology. Journal of Asian Studies 54(4), 968-96.

Ostrom, Elinor. 1992. Crafting Institutions for Self-Governing Irrigation Systems. San Francisco: ICS Press.

Park, Thomas. 1992. Early trends toward class stratification: Chaos, common property, and flood recession agriculture. American Anthropologist 94(1), 90-117.

Peterson, John A. and Stephen B. Acabado. 2015. Did the Little Ice Age contribute to the emergence of rice terrace farming in Ifugao, Philippines? National Museum Journal of Cultural Heritage 1, 1-10.

Saberwal, Vasant. 1997. Science and dessicationist discourse of the $20^{\text {th }}$ century. Environmental History 3, 309-43.

Scarborough, Vernon, John Schoenfelder, and J. Stephen Lansing. 2000. Ancient water management and landscape transformation at Sebatu, Bali. Bulletin of the IndoPacific Prehistory Association Bulletin 20, 79-92.

Schoenfelder, John. 2003. Negotiating poise in a multi-hierarchical world: an archaeological exploration of irrigated rice agriculture, ideology, and political balances in the coevolution of intersecting complex networks in Bali. PhD Dissertation, Department of Anthropology, UCLA, Los Angeles, California.

Schoenfelder, John. 2000. The Co-evolution of agricultural and sociopolitical systems in Bali. The Indo-Pacific Prehistory Association Bulletin 20 (Melaka Papers, Volume 4). 
Scott, William H. 1969. On the Cordillera: A Look at the Peoples and Cultures of the Mountain Province. Manila: CS Enterprises.

Scott, William H. 1970. Igorot responses to Spanish aims: 1576-1896. Philippine Studies $18,695-717$.

Scott, William H. 1974. The Discovery of the Igorots: Spanish Contact with the Pagans of Northern Luzon. Quezon City: New Day Publishers.

Scott, William H. 1982 The Spanish occupation of the Cordillera in the $19^{\text {th }}$ century. In Philippine Social History: Global and Local Transformations, A. McCoy and E. de Jesus (eds.), pp. 39-56. Honolulu: University of Hawaii Press.

Tang, Shui Yan. 1992. Institutions and collective action: Self-governance in irrigation. San Francisco: ICS Press.

Wittfogel, Karl. 1955. Development aspects of hydraulic societies. In Irrigation Civilizations: A Comparative Study, J. Steward (ed.) pp. 43-52. Social Science Monographs 1. Pan American Union: Washington, DC. 